\title{
Effect of temperature and concentration on benzoyl peroxide bleaching efficacy and benzoic acid levels in whey protein concentrate
}

\author{
T. J. Smith, ${ }^{*}$ P. D. Gerard, $†$ and M. A. Drake* \\ *Department of Food, Bioprocessing and Nutrition Sciences, Southeast Dairy Foods Research Center, North Carolina State University, \\ Raleigh 27695 \\ †Department of Mathematical Sciences, Clemson University, Clemson, SC 29634
}

\begin{abstract}
Much of the fluid whey produced in the United States is a by-product of Cheddar cheese manufacture and must be bleached. Benzoyl peroxide (BP) is currently 1 of only 2 legal chemical bleaching agents for fluid whey in the United States, but benzoic acid is an unavoidable by-product of BP bleaching. Benzoyl peroxide is typically a powder, but new liquid BP dispersions are available. A greater understanding of the bleaching characteristics of $\mathrm{BP}$ is necessary. The objective of the study was to compare norbixin destruction, residual benzoic acid, and flavor differences between liquid whey and $80 \%$ whey protein concentrates (WPC80) bleached at different temperatures with 2 different benzoyl peroxides (soluble and insoluble). Two experiments were conducted in this study. For experiment 1, 3 factors (temperature, bleach type, bleach concentration) were evaluated for norbixin destruction using a response surface model-central composite design in liquid whey. For experiment 2, norbixin concentration, residual benzoic acid, and flavor differences were explored in WPC80 from whey bleached by the 2 commercially available $\mathrm{BP}$ (soluble and insoluble) at $5 \mathrm{mg} / \mathrm{kg}$. In liquid whey, soluble BP bleached more norbixin than insoluble BP, especially at lower concentrations (5 and $10 \mathrm{mg} / \mathrm{kg}$ ) at both cold $\left(4^{\circ} \mathrm{C}\right)$ and hot $\left(50^{\circ} \mathrm{C}\right)$ temperatures. The WPC80 from liquid whey bleached with $\mathrm{BP}$ at $50^{\circ} \mathrm{C}$ had lower norbixin concentration, benzoic acid levels, cardboard flavor, and aldehyde levels than WPC80 from liquid whey bleached with $\mathrm{BP}$ at $4^{\circ} \mathrm{C}$. Regardless of temperature, soluble BP destroyed more norbixin at lower concentrations than insoluble BP. The WPC80 from soluble-BP-bleached wheys had lower cardboard flavor and lower aldehyde levels than WPC80 from insoluble-BP-bleached whey. This study suggests that new, soluble (liquid) BP can be used at lower concentrations than insoluble BP to achieve equivalent bleaching
\end{abstract}

Received June 1, 2015.

Accepted July 23, 2015.

${ }^{1}$ Corresponding author: maryanne_drake@ncsu.edu and that less residual benzoic acid remains in WPC80 powder from liquid whey bleached hot $\left(50^{\circ} \mathrm{C}\right)$ than cold $\left(4^{\circ} \mathrm{C}\right)$, which may provide opportunities to reduce benzoic acid residues in dried whey ingredients, expanding their marketability.

Key words: benzoyl peroxide, benzoic acid, whey protein concentrate, bleaching

\section{INTRODUCTION}

Dried whey ingredients provide significant value to the dairy industry. They possess many useful functional properties, such as gelation, thermal stability, foam formation, and emulsification properties, and provide many health benefits, including exercise recovery, weight management, cardiovascular health, anti-cancer effects, anti-infection activity, wound repair, and infant nutrition (Foegeding et al., 2002; Miller, 2005; O'Connell and Flynn, 2007; Smithers, 2008). Much of the whey produced in the United States is a by-product of Cheddar cheese manufacture. Cheddar cheese in the United States is typically colored with annatto (norbixin), a carotenoid extracted from the seed of the Bixa orellana shrub (Scotter, 2009). Approximately 10\% of annatto partitions into the liquid whey during Cheddar cheese manufacture (Smith et al., 2014).

To provide a colorless whey ingredient, colored liquid whey must be bleached; however, the use of chemical bleaching agents has detrimental effects, including off-flavor development, chemical residues, and protein functional changes (Listiyani et al., 2011; Jervis et al., 2012). There are currently 2 chemical bleaching agents approved for use in liquid whey in the United States, hydrogen peroxide (HP) and benzoyl peroxide (BP) (21CFR184.1366 and 21CFR184.1157, respectively). Bleaching of liquid whey has been extensively studied, and it has been consistently demonstrated that BP results in greater norbixin destruction and less lipid oxidation and subsequent off-flavors than bleaching with HP (Listiyani et al., 2012; Jervis et al., 2012; Fox et al., 2013; Jervis et al., 2015). Benzoyl peroxide reacts with oxidizable compounds in the liquid whey and is 
converted into water-soluble benzoic acid (BA). Benzoic acid residues are a concern because of restrictions in international markets, especially China. Because of the breakdown of BP into BA, BP is not an approved bleaching agent for whey ingredients in China or Japan (USDA 2013). In Canada, BP is allowed to be used as a bleaching agent in fluid whey not to be used in infant formula, at a maximum concentration of $100 \mathrm{mg} / \mathrm{kg} \mathrm{BP}$ (CFIA, 2008).

The safety of BA has been extensively studied (Sharratt et al., 1964; Nair, 2001; Qi et al., 2009). Benzoic acid and its salt are used in the food industry as preservatives with antibacterial, yeast, and fungal properties (Chipley, 1993). Sieber et al. (1995) found native BA in dairy products, especially fermented dairy products, at concentrations as high as $50 \mathrm{mg} / \mathrm{kg}$ (Sieber et al., 1995), and Qi et al. (2009) reported BA concentrations in Chinese infant formula as high as $85 \mathrm{mg} /$ $\mathrm{kg}$ and in milk powder as high as $110 \mathrm{mg} / \mathrm{kg}$. Listiyani et al. (2011) reported concentrations in BP-bleached $34 \%$ whey protein concentrate (WPC34) of 272 and $634 \mathrm{mg} / \mathrm{kg}$, depending on BP concentration used to bleach liquid whey at $60^{\circ} \mathrm{C}(50$ and $100 \mathrm{mg} / \mathrm{kg}$, respectively). In commercial $80 \%$ whey protein concentrate (WPC80) from BP bleached whey, 30 to $60 \mathrm{mg} / \mathrm{kg}$ BA were reported (Listiyani et al., 2011), but BP concentrations and conditions were not identified. Jervis et al. (2015) evaluated the effect of solids concentration at bleaching on residual BA. Benzoic acid concentrations in sweet whey powder (SWP) from BP-bleached (50 $\mathrm{mg} / \mathrm{kg} \mathrm{BP}$ ) whey of 130 or $420 \mathrm{mg} / \mathrm{kg}$ were reported, depending on total solids concentration when bleached ( $6.7 \%$ solids and $14 \%$ solids, respectively). These studies suggest that parameters in addition to BP concentration affect residual BA in dried whey ingredients.

The Joint Expert Committee for Food Additives has set the acceptable daily intake for BA and its salts (benzoate calcium, potassium, and sodium), benzaldehyde, benzyl acetate, and benzyl alcohol at 0 to $5 \mathrm{mg} /$ $\mathrm{kg}$ of BW (WHO, 1996). The Joint Expert Committee for Food Additives has also stated that no safety concern exists for BP in bleaching of whey when used at up to $100 \mathrm{mg} / \mathrm{kg}$ (JECFA, 2004). Benzoic acid is generally recognized as safe, but exposure to BA has been linked to eye, skin, and respiratory-tract irritation (Qi et al., 2009); skin sensitization (do Nascimento Filho et al., 2004); and nonimmunological contact reactions such as asthma, urticaria, metabolic acidosis, and convulsions (WHO, 2000; Tfouni and Toledo, 2002). Because of health concerns and international restrictions of $\mathrm{BP}$ use because of BA residues, it is important to investigate possible methods of reducing BA residues in dried whey protein ingredients. Benzoyl peroxide suspended in liquid medium, rather than powder, has recently come to the market and is commercially available. The objectives of this study were to compare the bleaching characteristics of commercially available soluble (liquid) and insoluble (powder) BP at different concentrations $(5,10,25,50 \mathrm{mg} / \mathrm{kg} \mathrm{BP}$ ) and temperatures (4 and $50^{\circ} \mathrm{C}$ ), and to determine their effect on $\mathrm{BA}$ residues in WPC 80 bleached at 4 and $50^{\circ} \mathrm{C}$.

\section{MATERIALS AND METHODS}

\section{Experimental Overview}

Two experiments (experiments 1 and 2) were included in this study. The purpose of experiment 1 was to determine the effects of $\mathrm{BP}$ concentration and temperature on norbixin destruction in liquid whey using soluble or insoluble $\mathrm{BP}$ and to generate a response surface and prediction equation for each temperatureBP treatment. Liquid Cheddar whey was manufactured and bleached at 2 temperatures $\left(4\right.$ and $50^{\circ} \mathrm{C}$ ), using 2 commercial forms of BP at 4 concentrations (5, 10, 25, and $50 \mathrm{mg} / \mathrm{kg})$. Samples were taken at $9\left(50^{\circ} \mathrm{C}\right.$ treatment; $1,5,10,15,20,25,30,45$, and $60 \mathrm{~min})$ or $5\left(4^{\circ} \mathrm{C}\right.$ treatment; $1,2,4,6$, and $16 \mathrm{~h}$ ) time points for norbixin analysis. Experiment 2 determined the effect of temperature and BP type (soluble or insoluble) on residual $\mathrm{BA}$ and flavor properties of WPC80. Conditions for experiment 2 were based on the results of experiment 1. Bleaching liquid whey with $5 \mathrm{mg} / \mathrm{kg} \mathrm{BP}$ was selected for experiment 2. The prediction equations generated in experiment 1 predicted a norbixin destruction level of $90 \%$ using $5 \mathrm{mg} / \mathrm{kg}$ soluble $\mathrm{BP}$ at $50^{\circ} \mathrm{C}$. A norbixin destruction level of $90 \%$ approximates the bleaching efficacy of BP treatments reported previously in literature (Listiyani et al., 2011; Jervis et al., 2012; Jervis et al., 2015). The prediction equations generated in experiment 1 also predicted that approximately $5 \mathrm{mg} /$ $\mathrm{kg}$ soluble BP at $4^{\circ} \mathrm{C}$ would destroy $40 \%$ of norbixin in $1 \mathrm{~h}$, which is equivalent to or greater than HP bleaching in previous literature (Jervis et al., 2012; Campbell et al., 2013; Jervis et al., 2015). The WPC80 powders were manufactured from liquid whey at 2 temperatures (4 and $50^{\circ} \mathrm{C}$ ), with $5 \mathrm{mg} / \mathrm{kg}$ of each of the 2 commercial forms of BP.

\section{Composition Analysis}

The liquid whey and WPC80 powders were analyzed for TS, fat, and CP. Total solids were determined by vacuum oven drying (AOAC International, 2000; method number 990.20; 33.2.44), fat by ether extraction (AOAC International, 2000; method number 989.05; 
33.2.26), and protein by the Kjeldahl method (AOAC International, 2000; method number 991.20; 33.2.11). All samples were measured in duplicate.

\section{Whey Production and Bleaching}

Bleaching of Liquid Whey. Raw whole milk, $195 \mathrm{~kg}$, was obtained from the North Carolina State University Dairy Research and Education Farm. Milk was pasteurized $(720 \mathrm{~kg} / \mathrm{h})$ with a plate heat exchanger (model T4 RGS-16/2, SPX Flow Technology, Greensboro, NC) at $72^{\circ} \mathrm{C}$ with a hold time of $16 \mathrm{~s}$. The milk was then cooled to $31^{\circ} \mathrm{C}$ and transferred to a cheese vat (Kusel Equipment, Watertown, WI). A standard colored Cheddar cheesemaking procedure was then followed as described by Park et al. (2014), and colored liquid whey was obtained. The liquid whey was HTST pasteurized under the same parameters as the milk, and fat-separated. Pasteurized liquid whey $(750 \mathrm{~mL})$ was then placed into autoclaved 1-L amber glass jars (VWR International, Radnor, PA) and held in a water bath at either 4 or $50^{\circ} \mathrm{C}$ until desired temperature was reached. Once temperature was reached, BP [soluble, Arkema (liquid), King of Prussia, PA, or insoluble, Oxylite Type XX (powder), Nelson Jameson, Marshfield, WI] at the appropriate concentration $(5,10,25$, or $50 \mathrm{mg} / \mathrm{kg}$ ) was added to each whey. Whey samples $(0.5 \mathrm{~mL})$ were taken $(1,5,10,15,20,25,30,45$, and $60 \mathrm{~min}$ for $50^{\circ} \mathrm{C} ; 1,2,4,6$, and $16 \mathrm{~h}$ for $4^{\circ} \mathrm{C}$ ) and immediately added to $2 \mathrm{~mL}$ of dilution solution $(80 \%$ acetonitrile, $20 \%$ HPLC water, and $0.1 \% \mathrm{wt} / \mathrm{vol}$ formic acid, EMD Chemicals Inc., Gibbstown, NJ) to suspend the bleaching reaction. Samples were then stored at $-20^{\circ} \mathrm{C}$ until norbixin extraction. Unbleached controls were also evaluated and sampled. This experiment was replicated 3 times.

WPC80 Bleaching and Production. Liquid whey was produced as described above. After fat separation and pasteurization, liquid whey was separated into 6 batches $(30 \mathrm{~kg})$ using sanitized 38-L stainless steel milk cans, covered, and placed into water baths at desired temperatures $\left(4^{\circ} \mathrm{C}, 50^{\circ} \mathrm{C}\right)$. Once the desired temperature was reached, bleaching (control with no bleach at 4 or $50^{\circ} \mathrm{C}, 5 \mathrm{mg} / \mathrm{kg}$ insoluble $\mathrm{BP}$ at 4 or $50^{\circ} \mathrm{C}, 5 \mathrm{mg} /$ $\mathrm{kg}$ soluble BP at 4 or $50^{\circ} \mathrm{C}$ ) commenced. All treatments were held or bleached for $1 \mathrm{~h}$ at their respective temperatures. After bleaching, the whey underwent UF and diafiltration (DF) to concentrate the protein to $80 \%$ on a dry weight basis (18\% solids) as described by Park et al. (2014). Briefly, the UF system (model Pellicon 2, Millipore Inc., Billerica, MA) using 5 cartridges of polyethersulfone membrane filters (model P2B010V05, nominal separation cutoff $=10,000 \mathrm{kDa}$, surface area $=0.5 \mathrm{~m}^{2}$ ) was cleaned before use with a $0.1 N$ sodium hydroxide solution (VWR international) followed by a rinse of deionized water. Total deionized water addition during $\mathrm{DF}$ was $50 \%$ of the original weight of the liquid whey. Protein concentration was confirmed using a Sprint Rapid Protein Analyzer (CEM Corp., Matthews, NC). Percent solids was analyzed using the Smart System 5 moisture/solids analyzer (CEM Corp.). The total time for UF was approximately $3 \mathrm{~h}$. The WPC80 retentates were then dried in a spray drier (model Lab 1, Anhydro Inc., Soeberg, Denmark) with an inlet temperature of $200^{\circ} \mathrm{C}$ and outlet temperature of $90^{\circ} \mathrm{C}$. The powders were collected in Mylar bags (TF4000, Impak Corp., Central City, SD) and stored at $-80^{\circ} \mathrm{C}$ until analysis. The experiment was replicated 3 times.

\section{Color Analysis}

Hunter L* (lightness), $a^{*}$ (red-green), and b* (yellow-blue) values for WPC80 powders and reconstituted WPC80 liquids (10\% solids, wt/vol) were determined using a Minolta chroma meter (CR-410, Ramsey, NJ), using methods described by Fox et al. (2013). Measurements were taken in triplicate.

\section{Norbixin Extraction}

Norbixin extraction from liquid whey and WPC80 powder was performed following the procedure described by Campbell et al. (2014), slightly modified for liquid whey. For WPC80 powder, $1 \mathrm{~g}$ of powder was placed into a 10-mL volumetric flask, and HPLCgrade water (EMD Chemicals) was added to volume. The sample was then mixed for 10 min after which $1 \mathrm{~g}$ of WPC80 solution was placed into a $5-\mathrm{mL}$ volumetric flask and filled to volume with dilution solution ( $80 \%$ acetonitrile, $20 \%$ HPLC water, and $0.1 \% \mathrm{wt} / \mathrm{vol}$ formic acid, EMD Chemicals). The solution was again mixed for $10 \mathrm{~min}$, after which $2 \mathrm{~mL}$ of sample was placed into an Eppendorf tube (VWR International) and centrifuged at $14,000 \times g$ for $5 \mathrm{~min}$ at $25^{\circ} \mathrm{C}$. The clear supernatant was removed and placed into a vial (Phenomenex, Torrance, CA) for injection.

For liquid whey, $0.5 \mathrm{~mL}$ of bleached or unbleached whey was added to $2 \mathrm{~mL}$ of dilution solution $(80 \%$ acetonitrile, $20 \%$ HPLC water, and $0.1 \% \mathrm{wt} / \mathrm{vol}$ formic acid) at each time point. Two milliliters of sample was placed in an Eppendorf tube (VWR International) and centrifuged at $14,000 \times g$ at $25^{\circ} \mathrm{C}$ for $5 \mathrm{~min}$. The clear supernatant was removed and placed into a vial (Phenomenex) for injection.

Norbixin was quantified by HPLC (Breeze HPLC, Waters, Milford, MA) using an isocratic mobile phase 
( $70 \%$ acetonitrile/30\% water with $0.1 \%$ formic acid, EMD Chemicals) at a flow rate of $1 \mathrm{~mL} / \mathrm{min}$ pumped through a binary pump (Waters 1525, Waters). Fifty microliters of sample was injected (Waters 2707 autosampler) onto the column (Phenomenex Kinetex 2.6- $\mu \mathrm{m}$ particle size, $10-\mathrm{cm}$ length, 4.6-mm i.d., $100 \AA$ pore size) at $40^{\circ} \mathrm{C}$. Sample was analyzed using a photodiode array detector (Waters 2998) with a maxima of 482 $\mathrm{nm}$. Sample run time was $3 \mathrm{~min}$. All WPC80 and liquid wheys were extracted and evaluated in triplicate. Norbixin destruction was determined by calculating the percent reduction of norbixin concentration in the bleached WPC80 or liquid whey compared with the norbixin concentration of the unbleached control WPC80 or liquid whey.

\section{GC-MS}

Selected volatile compounds were extracted from WPC80 powder by headspace solid-phase microextraction followed by GCMS using the method reported by Campbell et al. (2011) with modification. Each WPC80 was rehydrated to $10 \%$ solids (wt/vol) using HPLC water (EMD Chemicals Inc.), and $5 \mathrm{~mL}$ were added to 20-mL autosampler vials with steel screw tops containing silicone Teflon faced septa (Microliter Analytical, Suwannee, FL) along with $10 \%$ (wt/vol) salt. Ten microliters of $81 \mathrm{mg} / \mathrm{kg}$ 2-methyl-3-heptanone in methanol (Sigma-Aldrich, Milwaukee, WI) was added as an internal standard. Samples were injected by a CombiPal autosampler (CTC Analytics, Zwingen, Switzerland) into an Agilent 6890N GC with 5973 inert MSD (Agilent Technologies Inc., Santa Clara, CA). Samples were held at $10^{\circ} \mathrm{C}$ before fiber exposure and brought up to $40^{\circ} \mathrm{C}$ for $25 \mathrm{~min}$ before $30 \mathrm{~min}$ of fiber exposure of a 1-cm divinylbenzene/carboxen/polydimethylsiloxane fiber at $31 \mathrm{~mm}$ with $4 \mathrm{~s}$ of pulsed agitation at 250 $\mathrm{rpm}$. The fibers were injected for $5 \mathrm{~min}$ at a depth of $50 \mathrm{~mm}$. The GC method used a start temperature of $40^{\circ} \mathrm{C}$ for 3 min with a ramp rate of $10^{\circ} \mathrm{C} / \mathrm{min}$ until $250^{\circ} \mathrm{C}$ was reached. The sample was then held for 5 min. A Zb-5ms (Zb-5ms, 30-m length $\times 0.25$-mm i.d. $\times 0.25-\mu \mathrm{m}$ film thickness, Phenomenex) column was used with a constant flow rate of $1 \mathrm{~mL} / \mathrm{min}$ in SIM and SCAN mode. Purge time was $1 \mathrm{~min}$. Compounds were identified using the National Institute of Standards and Technology (2005; Gaithersburg, MD) mass spectral database and comparison of retention indices and mass spectra of authentic standards. Retention indexes were based on an alkane series (Sigma-Aldrich). Internal standard concentration was used to calculate the relative abundance of each compound. The analyses were conducted in triplicate.

\section{Descriptive Sensory Analysis}

Descriptive sensory analysis was conducted on WPC80 manufactured in experiment 2 in compliance with North Carolina State University Institutional Review Board for Human Subjects guidelines. Samples were rehydrated to $10 \%$ solids (wt/vol) and dispensed into 59-mL cups with lids (Solo Cup Co., Champaign, IL) labeled with random 3-digit codes. Eight panelists (23-45 yr, 6 females, 2 males), each with more than $100 \mathrm{~h}$ of experience with descriptive analysis of dried dairy ingredients and the Spectrum 0- to 15-point universal scale (Meilgaard et al. 2007), evaluated the samples using an established sensory language (Wright et al., 2009). Each rehydrated sample was evaluated by each panelist in duplicate. Compusense 5 version 5.6 was used for data collection (Compusense, Guelph, Canada).

\section{BA Extraction and Measurement}

Benzoic acid in the WPC80 powders was determined by HPLC-photodiode array as described by Listiyani et al. (2011). The WPC80 (2.5 g) was measured into a $50-\mathrm{mL}$ volumetric flask, with $5 \mathrm{~mL}$ of $1 \mathrm{M}$ zinc acetate (Mallinckrodt Baker Inc., Phillipsburg, NJ) solution and $5 \mathrm{~mL}$ of $0.25 \mathrm{M}$ potassium hexacyanoferrate(II) trihydrate (Alfa Aesar, Ward hill, MA), and the flask was filled to volume with HPLC water (EMD Chemicals). The samples were manually shaken for $1 \mathrm{~min}$, transferred to centrifuge tubes (VWR International), and centrifuged for $10 \mathrm{~min}$ at $10,000 \times g$ at $25^{\circ} \mathrm{C}$. The supernatant was filtered with a $0.45-\mu \mathrm{m}$ nylon filter (VWR International), and $750 \mu \mathrm{L}$ of filtrate and 750 $\mu \mathrm{L}$ of mobile phase were added to HPLC vials (Phenomenex). Standard curves ranging from 0.1 to $50 \mathrm{mg} /$ $\mathrm{kg}$ BA (VWR International) were used to quantify BA in WPC80. High-performance liquid chromatography analysis (Breeze HPLC, Waters) was performed using reversed phase separation (Kinetex C18, $2.6 \mu \mathrm{m}, 100 \times$ $4.6 \mathrm{~mm}$; Phenomenex). The photodiode array detector was set at $230 \mathrm{~nm}$. The mobile phase consisted of $4 \%$ methanol (VWR International) and 96\% $0.02 \mathrm{M}$ ammonium acetate (VWR International) buffer with a flow rate of $1 \mathrm{~mL} / \mathrm{min}$ pumped through a binary pump (Waters 1525, Waters). Twenty microliters of sample was injected (Waters 2707 autosampler) onto the column.

\section{Statistical Analysis}

In experiment 1, 3 factors (temperature, bleach type, bleach concentration) were evaluated for norbixin destruction using a response surface model-central com- 


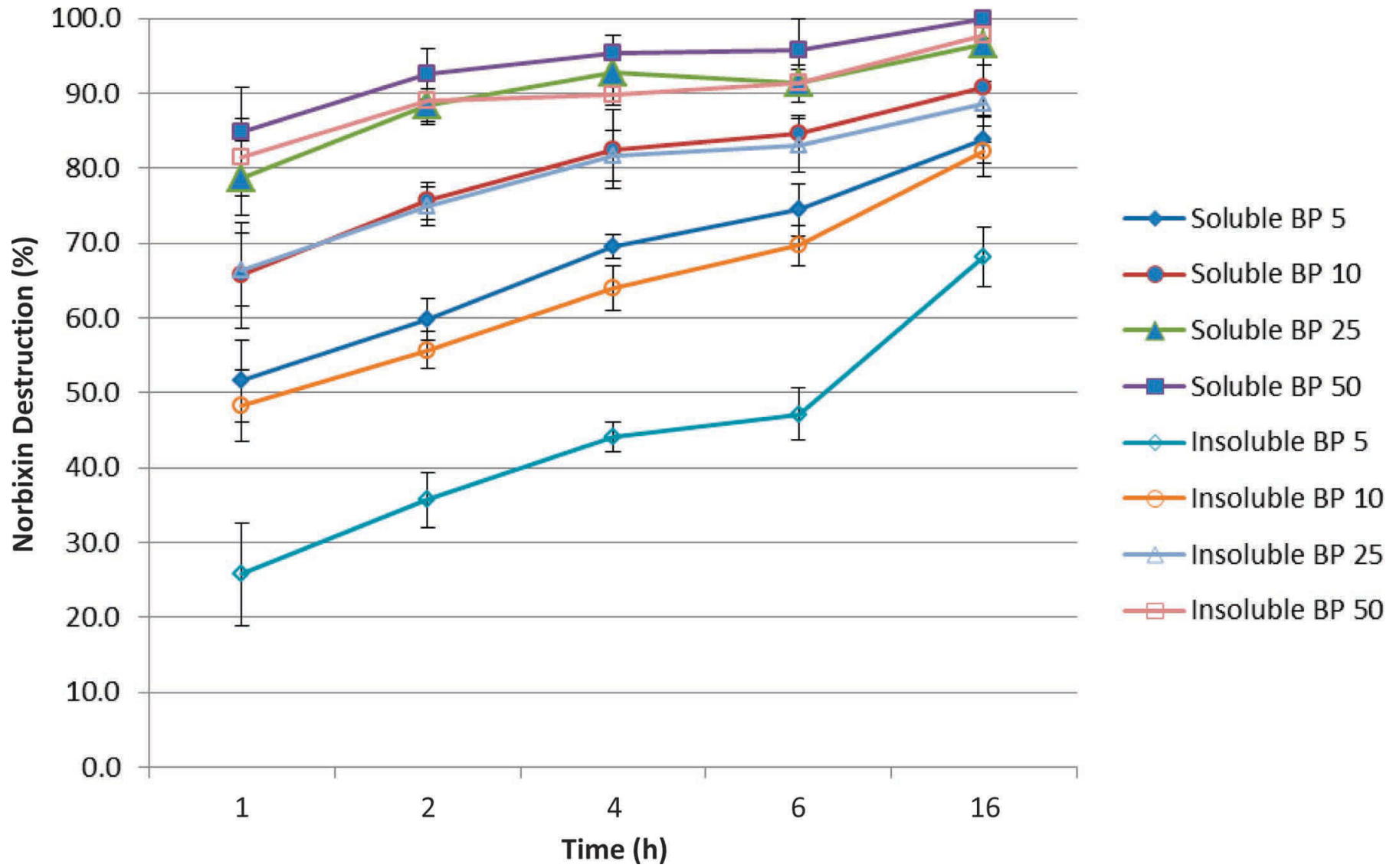

Figure 1. Percent norbixin destruction (means $\pm \mathrm{SD}$ ) in liquid whey bleached by $5,10,25$, or $50 \mathrm{mg} / \mathrm{kg}$ insoluble or soluble benzoyl peroxide (BP) at $4^{\circ} \mathrm{C}$ for $16 \mathrm{~h}$. Color version available online.

posite design, and response surface methodology was performed on these data using PROC RSREG (SAS version 9.2; SAS Institute Inc., Cary, NC) to create a predictive equation for log norbixin destruction as a function of $\mathrm{BP}$ concentration and time for a given temperature and BP form for fluid whey. A secondorder response surface was fit to create a second-order polynomial function of concentration and time for each temperature and BP form used in the experiment. Data from experiment 2 were analyzed by ANOVA with means separation (XLSTAT, version 2013.5.03, Addinsoft, New York, NY). Differences were analyzed by Tukey's honestly significant difference.

\section{RESULTS AND DISCUSSION}

\section{Experiment 1: Norbixin Destruction}

Benzoyl peroxide (soluble or insoluble), temperature, and $\mathrm{BP}$ concentration all influenced norbixin destruction $(P<0.05)$. At $4^{\circ} \mathrm{C}$, and 5,10 , and $25 \mathrm{mg} / \mathrm{kg}$ con- centration, soluble BP destroyed more norbixin than the insoluble BP (Figure 1). The soluble BP at $50 \mathrm{mg} /$ $\mathrm{kg}$ bleached more norbixin than the insoluble BP until $16 \mathrm{~h}$ at which point norbixin was no longer detected (Figure 1). The insoluble BP, at $50 \mathrm{mg} / \mathrm{kg}$, reduced norbixin $97.8 \%$ compared with the unbleached control by $16 \mathrm{~h}$ at $4^{\circ} \mathrm{C}$ (Figure 1 ). At $4^{\circ} \mathrm{C}$, soluble $\mathrm{BP}$ was a more effective bleaching agent, especially at lower concentrations, than the insoluble BP.

At $50^{\circ} \mathrm{C}$, and 5 and $10 \mathrm{mg} / \mathrm{kg}$ concentration, the soluble BP bleached more norbixin than the insoluble $\mathrm{BP}$ at all time points (Figure 2). At 25 and $50 \mathrm{mg} /$ $\mathrm{kg} \mathrm{BP}$, the soluble BP bleached more norbixin than the insoluble BP until $45 \mathrm{~min}$, at which point norbixin was no longer detected (Figure 2). The insoluble BP reduced norbixin 97.7 and $99.0 \%$, respectively, at 25 and $50 \mathrm{mg} / \mathrm{kg}$ compared with the unbleached control after $45 \mathrm{~min}$ at $50^{\circ} \mathrm{C}$ (Figure 2). Like bleaching at $4^{\circ} \mathrm{C}$, soluble $\mathrm{BP}$ was more effective at bleaching liquid whey at $50^{\circ} \mathrm{C}$ than insoluble, although at higher concentrations $(25$ and $50 \mathrm{mg} / \mathrm{kg} \mathrm{BP}$ ) virtually all norbixin was destroyed by both soluble and insoluble BP. 


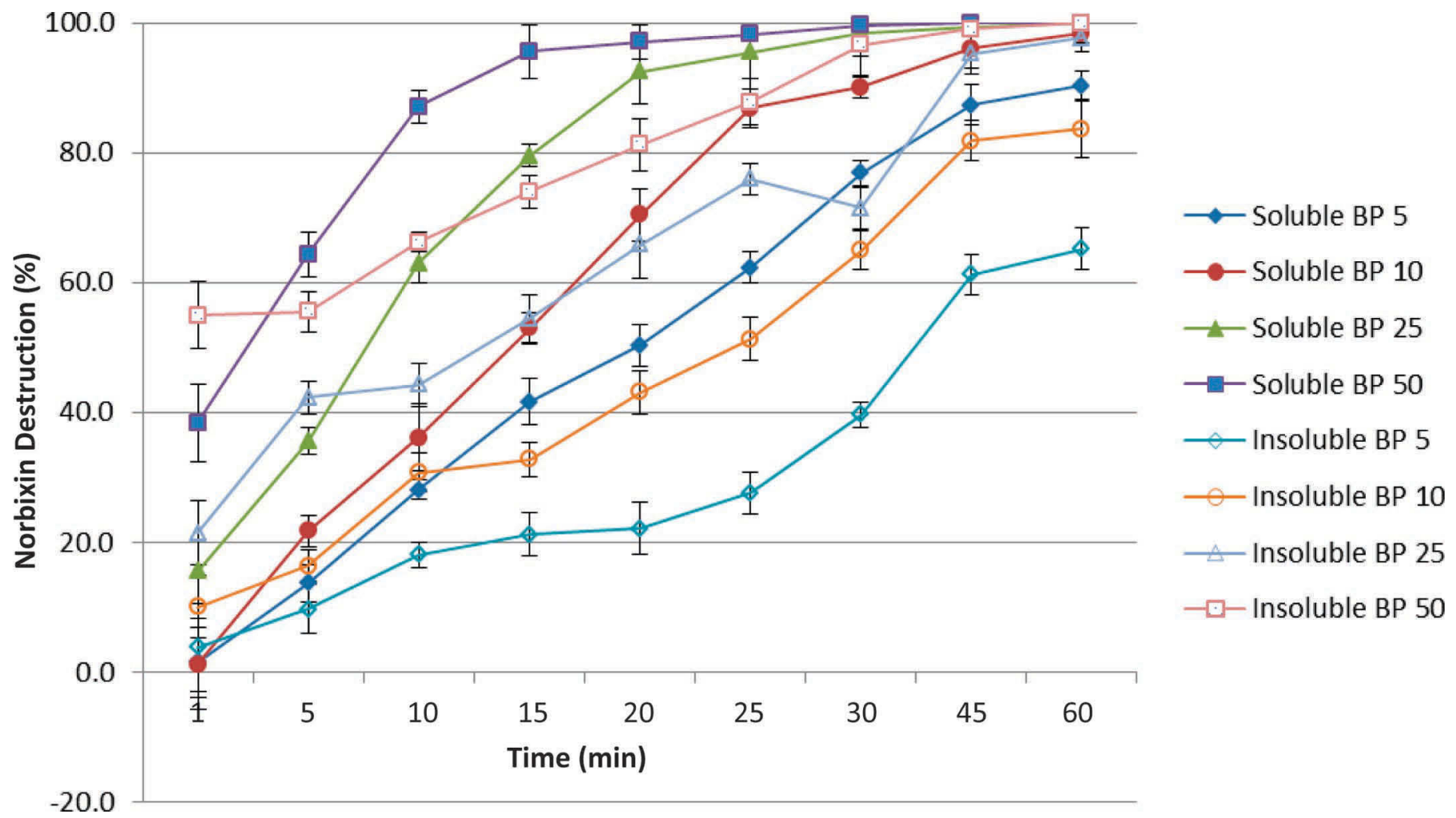

Figure 2. Percent norbixin destruction (means $\pm \mathrm{SD}$ ) in liquid whey bleached by $5,10,25$, or $50 \mathrm{mg} / \mathrm{kg}$ insoluble or soluble benzoyl peroxide (BP) at $50^{\circ} \mathrm{C}$ for $1 \mathrm{~h}$. Color version available online.

It is interesting to note that as $\mathrm{BP}$ concentration increased, the difference in norbixin destruction between the 2 different forms of BP decreased at both temperatures evaluated. This result suggests that at high concentrations of BP, little difference is seen between soluble and insoluble BP in relation to bleaching efficiency; however, the soluble BP was more effective than the insoluble BP as concentration decreased. This observation is important considering the need to reduce $\mathrm{BA}$ residue in the final product. The lowest concentration of $\mathrm{BP}$ to reduce norbixin is desired.

At $4^{\circ} \mathrm{C}$, the soluble $\mathrm{BP}$ at $5 \mathrm{mg} / \mathrm{kg}$ reduced norbixin concentration by $83.8 \%$ after $16 \mathrm{~h}$ (Figure 1). At $50^{\circ} \mathrm{C}$, the soluble BP at $5 \mathrm{mg} / \mathrm{kg}$ reduced norbixin by $90.4 \%$ in $1 \mathrm{~h}$ (Figure 2). Recent studies evaluating HP bleaching of fluid whey demonstrated that HP reduced norbixin concentration by 20 to $44 \%$ at 250 to $500 \mathrm{mg} /$ $\mathrm{kg}$ concentrations at temperatures ranging from 50 to $60^{\circ} \mathrm{C}$ (Jervis et al., 2012; Kang et al., 2012; Fox et al., 2013). Because HP is frequently used as a whey bleaching agent, it is likely that acceptable norbixin reduction in liquid whey is well below $90 \%$. Listiyani et al. (2011) bleached liquid whey at both 50 and $100 \mathrm{mg} / \mathrm{kg}$ (insoluble) BP and demonstrated a direct relationship between $\mathrm{BP}$ addition and subsequent $\mathrm{BA}$ levels in the final powder, demonstrating a need to minimize the BP concentration used to bleach whey. Using the prediction equations from this study, at $4^{\circ} \mathrm{C}$ (Figures 3 and 4), it would take approximately $6 \mathrm{mg} / \mathrm{kg}$ of the soluble $\mathrm{BP}$, and $10.5 \mathrm{mg} / \mathrm{kg}$ of insoluble $\mathrm{BP}$, to reduce norbixin by $45 \%$ in an hour (bleaching comparable to HP). At $50^{\circ} \mathrm{C}$ it would take approximately $0.5 \mathrm{mg} / \mathrm{kg}$ soluble $\mathrm{BP}$, and $6.5 \mathrm{mg} / \mathrm{kg}$ insoluble $\mathrm{BP}$, to reduce norbixin by $45 \%$ in $40 \mathrm{~min}$ (Figures 5 and 6 ). It is unlikely that a concentration as high as the maximum BP concentration in liquid whey determined by the Joint Expert Committee for Food Additives of $100 \mathrm{mg} / \mathrm{kg}$ would ever be necessary to reduce norbixin levels to desired levels. To reduce $\mathrm{BA}$ residues in whey protein ingredients, it is important to know exactly how much BP is necessary to reduce norbixin to acceptable levels. Using soluble $\mathrm{BP}$ allows for a significantly lower concentration to be used compared with BP in an insoluble form with subsequently less residual BA.

\section{Experiment 2}

Compositional Analysis of WPC80. No differences were detected $(P>0.05)$ in the mean values for solids, fat, or protein among the WPC80 (unbleached, 5 
$\mathrm{mg} / \mathrm{kg}$ soluble BP, $5 \mathrm{mg} / \mathrm{kg}$ insoluble BP, 4 and $50^{\circ} \mathrm{C}$ ). Moisture was $3.32 \pm 0.11 \%$, fat (dry basis) was $4.29 \pm$ $0.06 \%$, and protein (dry basis) was $80.7 \pm 0.45 \%$. No differences $(P>0.05)$ were found in mineral content (calcium, potassium, magnesium, sodium, iron, phosphorus; results not shown).

Color and Norbixin Destruction. All bleached powders were visibly whiter (higher $\mathrm{L}^{*}$ value) than the unbleached WPC80 (Table 1). The soluble BP $50^{\circ} \mathrm{C}$ $(5 \mathrm{mg} / \mathrm{kg})$ treatment was whiter $\left(\mathrm{L}^{*}\right.$ value) than the insoluble $4^{\circ} \mathrm{C}$ treatment. As expected, the yellowness ( $\mathrm{b}^{*}$ value) was reduced by both soluble and insoluble $\mathrm{BP}$ bleaching at 4 and $50^{\circ} \mathrm{C}$, but soluble $\mathrm{BP}$ had much lower yellowness than the insoluble-BP WPC80 at both 4 and $50^{\circ} \mathrm{C}(P<0.05$, Table 1$)$. These results are consistent with norbixin destruction results. Norbixin destruction in WPC80 from $5 \mathrm{mg} / \mathrm{kg}$ insoluble BP was 30 and $70 \%$ (4 and $50^{\circ} \mathrm{C}$, respectively) compared with the unbleached WPC80, whereas the norbixin destruction of WPC 80 from $5 \mathrm{mg} / \mathrm{kg}$ soluble BP was 55 and $93 \%$ (4 and $50^{\circ} \mathrm{C}$, respectively; Figure 7 ). These results are consistent with those performed in liquid whey from experiment 1 and with the predicted norbixin destruction values from the generated equations. These results are also consistent with norbixin destruction from insoluble BP reported by Jervis et al. (2012; 92.3\% norbixin destruction, $50 \mathrm{mg} / \mathrm{kg} \mathrm{BP}, 50^{\circ} \mathrm{C}$ ) in WPC 80 and Campbell et al. (2013; 91.6\% norbixin reduction, $50 \mathrm{mg} / \mathrm{kg} \mathrm{BP}, 50^{\circ} \mathrm{C}$ ) in SPC80. It is important to note that a direct comparison cannot be made due to the differences in commercial BP and that the WPC80 in this study was bleached at $5 \mathrm{mg} / \mathrm{kg}$ rather than $50 \mathrm{mg} /$ $\mathrm{kg}$. The results of this study, combined with those of Jervis et al. (2012) and Campbell et al. (2013), suggest that $5 \mathrm{mg} / \mathrm{kg}$ of soluble $\mathrm{BP}$ is as effective at reducing norbixin in the final product as $50 \mathrm{mg} / \mathrm{kg}$ insoluble BP.

Instrumental Volatile and Descriptive Analysis. Bleaching temperature and BP (soluble or insoluble) affected lipid oxidation and protein degradation compounds. The WPC80 bleached by soluble and insoluble BP had higher levels $(P>0.05)$ of 2 methylbutanal, hexanal, 2-pentyl furan, and nonanal than unbleached WPC80 (results not shown); these volatile compounds have been previously reported in dried whey products
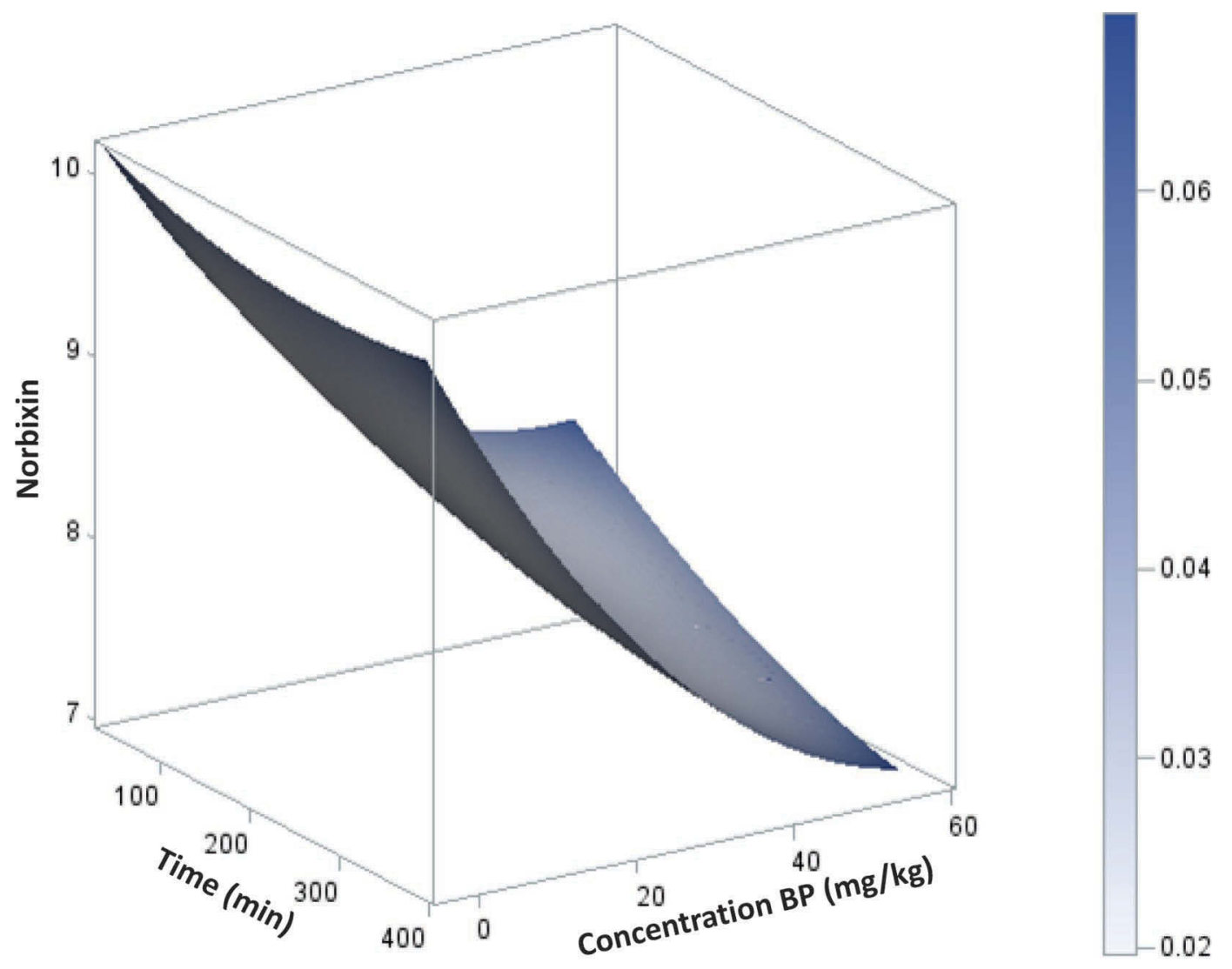

Figure 3. Response surface model of bleaching of fluid whey with insoluble benzoyl peroxide (BP) at $4^{\circ} \mathrm{C}$. Prediction equation: percent destruction $=100-\left\{\operatorname{INL}\left[9.88+(\right.\right.$ conc $\times-0.07)+($ time $\times-0.003)+\left(\right.$ conc $\left.^{2} \times 0.0006\right)+($ conc $\times$ time $\times-0.00004)+\left(\right.$ time $\left.\left.^{2} \times 0.000004\right)\right]+$ $1\} / 161.18$, where INL $=$ inverse $\log$, conc $=$ concentration of $\mathrm{BP}$, time $=$ bleaching time in minutes. Color version available online. 


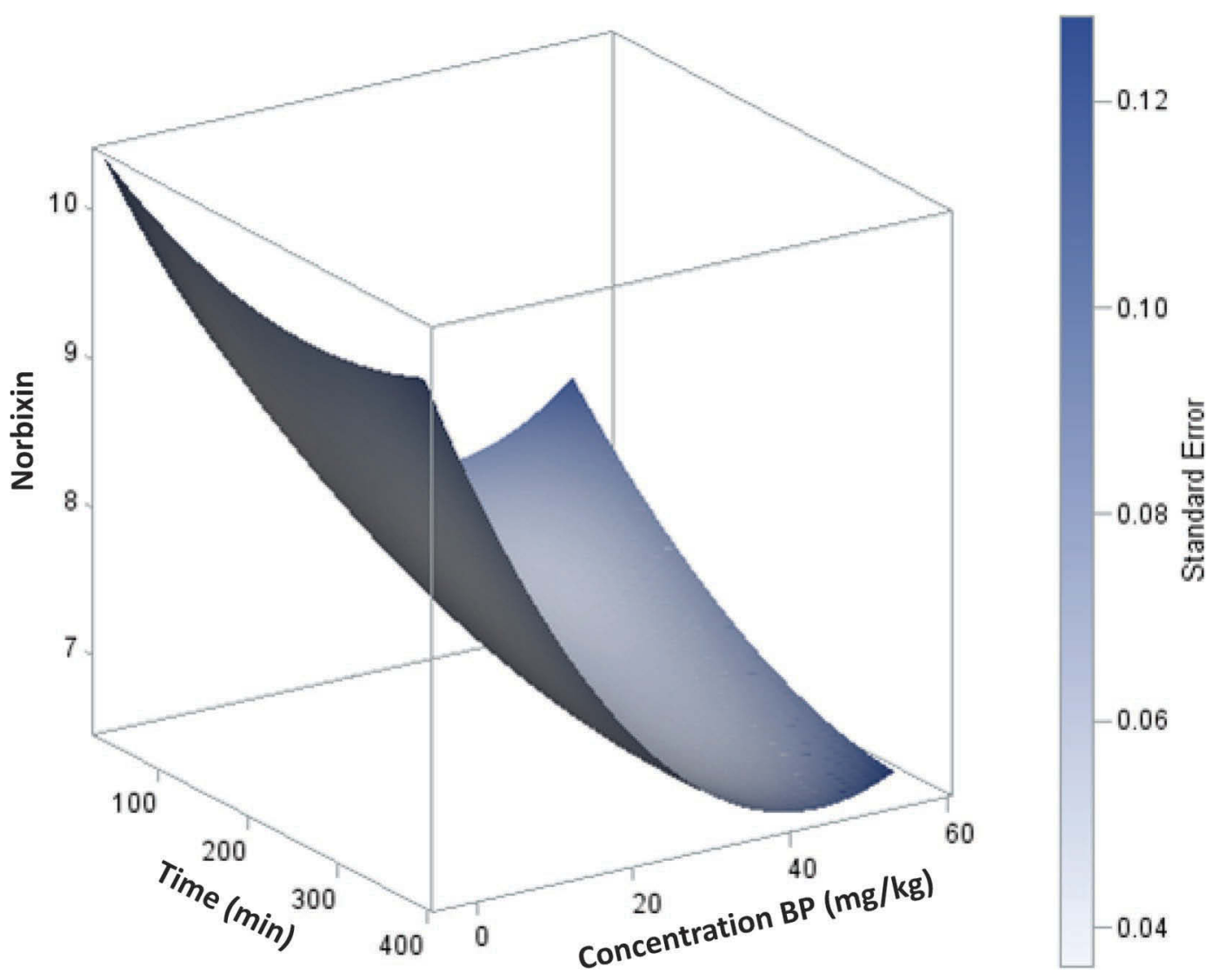

Figure 4. Response surface model of bleaching of fluid whey with soluble benzoyl peroxide $(\mathrm{BP})$ at $4^{\circ} \mathrm{C}$. Prediction equation: percent destruction $=100-\left\{\operatorname{INL}\left[9.97+(\operatorname{conc} \times-0.10)+(\right.\right.$ time $\times-0.006)+\left(\operatorname{conc}^{2} \times 0.001\right)+($ conc $\times$ time $\times-0.00005)+\left(\right.$ time $\left.\left.\left.{ }^{2} \times 0.00001\right)\right]+1\right\} / 161.18$, where INL $=$ inverse $\log$, conc $=$ concentration of $\mathrm{BP}$, time $=$ bleaching time in minutes. Color version available online.

(Wright et al., 2006; Croissant et al., 2009; Evans et al., 2010; Whitson et al., 2010; Listiyani et al., 2011; Jervis et al., 2012; Campbell et al., 2013). The WPC80 bleached by insoluble $\mathrm{BP}$ at $4^{\circ} \mathrm{C}$ had higher total aldehyde levels and higher levels of hexanal, 2-pentyl furan, and octanal than WPC 80 bleached by soluble BP at 4 or $50^{\circ} \mathrm{C}$ and WPC 80 bleached by insoluble $\mathrm{BP}$ at $50^{\circ} \mathrm{C}$ (Figure 8). Listiyani et al. (2012) and Fox et al. (2013) reported no differences among volatile compound levels between liquid whey bleached cold or hot $\left(4\right.$ or $68^{\circ} \mathrm{C}, 5$ or $50^{\circ} \mathrm{C}$, respectively) with insoluble $\mathrm{BP}$; however, 50 and $25 \mathrm{mg} / \mathrm{kg}$ insoluble $\mathrm{BP}$ were the lowest concentrations evaluated, and dried whey products were not evaluated. Campbell and Drake (2014) reported higher aldehyde levels in liquid whey bleached with various bleaching agents (HP, lactoperoxidase, exogenous peroxidase) warm $\left(35^{\circ} \mathrm{C}\right)$ compared with cold $\left(4^{\circ} \mathrm{C}\right)$. Discrepancies between the findings of Fox et al. (2013), Listiyani et al. (2012), and Campbell and Drake (2014) may be due to differences in processing parameters and bleaching agents. Listiyani et al. (2012) bleached liquid whey with insoluble $\mathrm{BP}$ at $68^{\circ} \mathrm{C}$, which could cause more lipid oxidation compared with the hot bleaching temperature $\left(50^{\circ} \mathrm{C}\right)$ used in the current study. Listiyani et al. (2012) and Fox et al. (2013) also bleached liquid whey using a higher concentration of BP (50 and 25 $\mathrm{mg} / \mathrm{kg}$, respectively) and evaluated liquid whey that had not been spray dried, which could also cause differences in lipid oxidation levels (Park et al., 2014). Campbell and Drake (2014) reported higher levels of aldehydes at $35^{\circ} \mathrm{C}$ compared with $4^{\circ} \mathrm{C}$ in WPC 80 from liquid whey bleached with HP, lactoperoxidase, or exogenous peroxidase rather than BP.

Descriptive analysis results were consistent with volatile compounds. The WPC 80 bleached at $4^{\circ} \mathrm{C}$ with insoluble $\mathrm{BP}$ was higher in cardboard flavor than the unbleached WPC80 and $50^{\circ} \mathrm{C}$ bleached WPC80 $(P<$ 0.05 ; Figure 8 ). The WPC 80 bleached at $4^{\circ} \mathrm{C}$ by soluble $\mathrm{BP}$ was also higher in cardboard flavor than the unbleached control $(P<0.05)$. Lipid oxidation products, such as the aldehydes found in elevated concentrations in the WPC 80 bleached by insoluble $\mathrm{BP}$ at $4^{\circ} \mathrm{C}$, are the source of cardboard flavor (Whitson et al., 2010). Sweet aromatic flavor was lower in all BP-bleached WPC80 
compared with the unbleached control, and WPC80 bleached at $4^{\circ} \mathrm{C}$ by insoluble $\mathrm{BP}$ had lower sweet aromatic flavor than WPC 80 bleached by soluble BP at 4 and $50^{\circ} \mathrm{C}$.

$\boldsymbol{B} \boldsymbol{A}$. At equivalent concentration, bleaching temperature, but not BP form (soluble or insoluble) had a significant effect on BA levels in WPC80 $(P<0.05$; Figure 9). The WPC80 BP bleached at $4^{\circ} \mathrm{C}$ had higher $\mathrm{BA}$ residues than the $\mathrm{WPC} 80$ bleached at $50^{\circ} \mathrm{C}$. Benzoic acid levels in UF permeate from WPC retentate bleached at $4^{\circ} \mathrm{C}$ were lower than $\mathrm{BA}$ residual levels in permeate from WPC retentate bleached at $50^{\circ} \mathrm{C}$. This result may be due to $\mathrm{BP}$ remaining unreacted during processing at cold temperatures. Unreacted BP could be concentrated during UF and subsequently spray dried with the WPC80 powder. It would then be free to break down over time into BA, resulting in higher levels of BA in WPC 80 bleached at $4^{\circ} \mathrm{C}$ than at $50^{\circ} \mathrm{C}$.

Listiyani et al. (2011) suggested that not all BP was converted into BA during processing because of residual BA levels in WPC34 and UF permeate being too low to account for the amount of $\mathrm{BP}$ added to liquid whey. Jervis et al. (2015) demonstrated higher levels of lipid oxidation, residual BA, and BA recovery efficiency in liquid whey that had been BP bleached (insoluble, $50 \mathrm{mg} / \mathrm{kg}$ ) at native solids levels (6.7\%) compared with liquid whey bleached with BP at increased solids (14\%). Bleaching efficacy for liquid wheys bleached at either solids level was the same (approximately 94\% norbixin destruction), but as the current study shows, $50 \mathrm{mg} / \mathrm{kg} \mathrm{BP}$ is a higher than necessary BP concentration to destroy virtually all norbixin in liquid whey. It is possible that at lower solids concentration, less BP degrades into BA during processing due to the decreased concentration of organics available for oxidation. Jervis et al. (2015) suggested that BA may bind to protein or solubilize in fat during the bleaching process. Moriguchi et al. (1968) and Wedzicha and Ahmed (1993) demonstrated that $\mathrm{BA}$ does bind to milk proteins. If BA binding to proteins takes place at a higher rate in liquid whey than it would as a dry powder (due to lack of BA mobility and subsequent protein contact and availability for reaction in the powder), then BA binding to whey proteins would also explain why BA

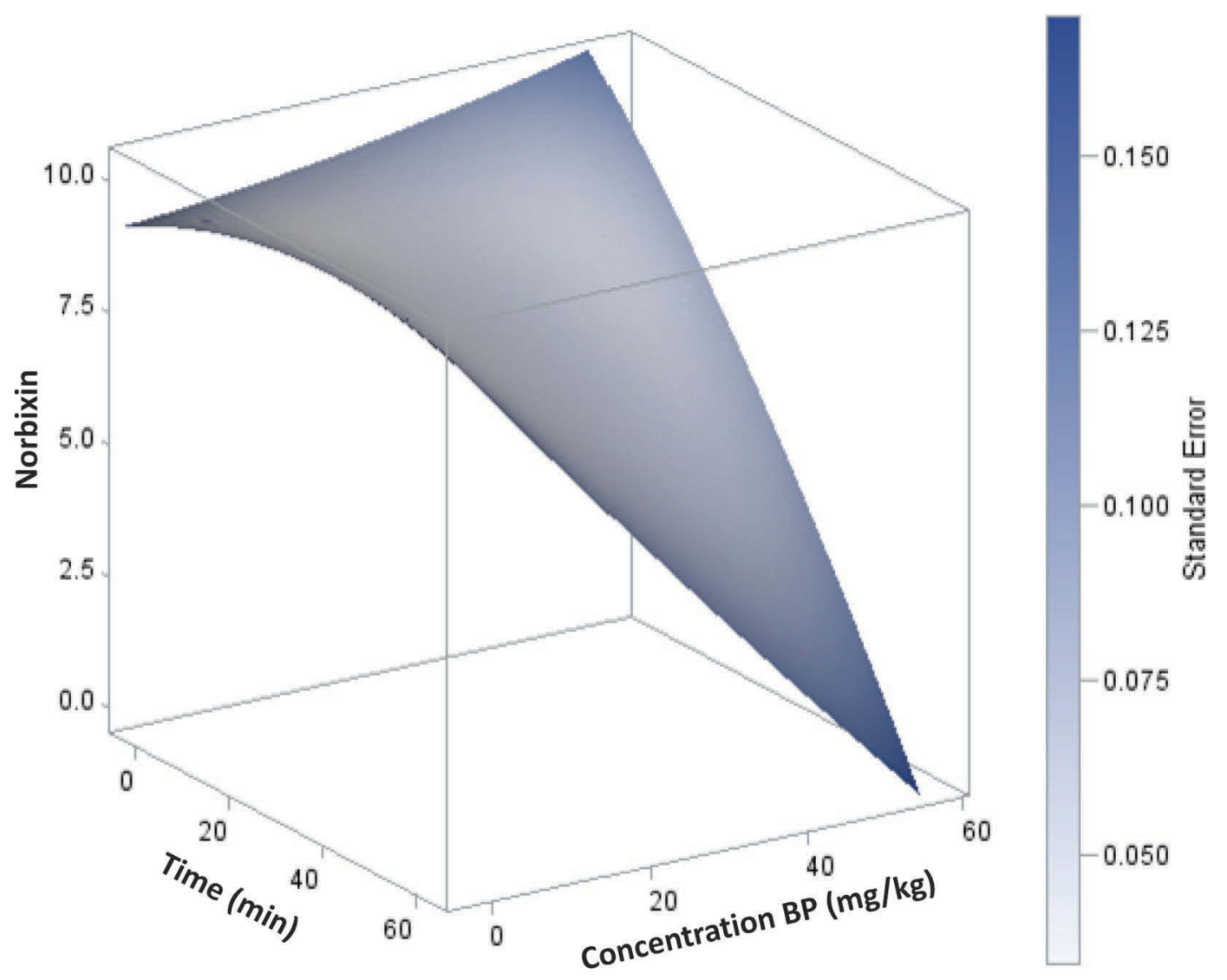

Figure 5. Response surface model of bleaching of fluid whey with insoluble benzoyl peroxide (BP) at $50^{\circ} \mathrm{C}$ Prediction equation: percent destruction $=100-\left\{\operatorname{INL}\left[9.36+(\operatorname{conc} \times-0.0004)+(\right.\right.$ time $\times 0.03)+\left(\right.$ conc $\left.^{2} \times 0.0002\right)+(\operatorname{conc} \times$ time $\times-0.002)+\left(\right.$ time $\left.\left.{ }^{2} \times-0.0006\right)\right]+$ $1\} / 161.18$, where INL $=$ inverse $\log$, conc $=$ concentration of $\mathrm{BP}$, time $=$ bleaching time in minutes. Color version available online. 


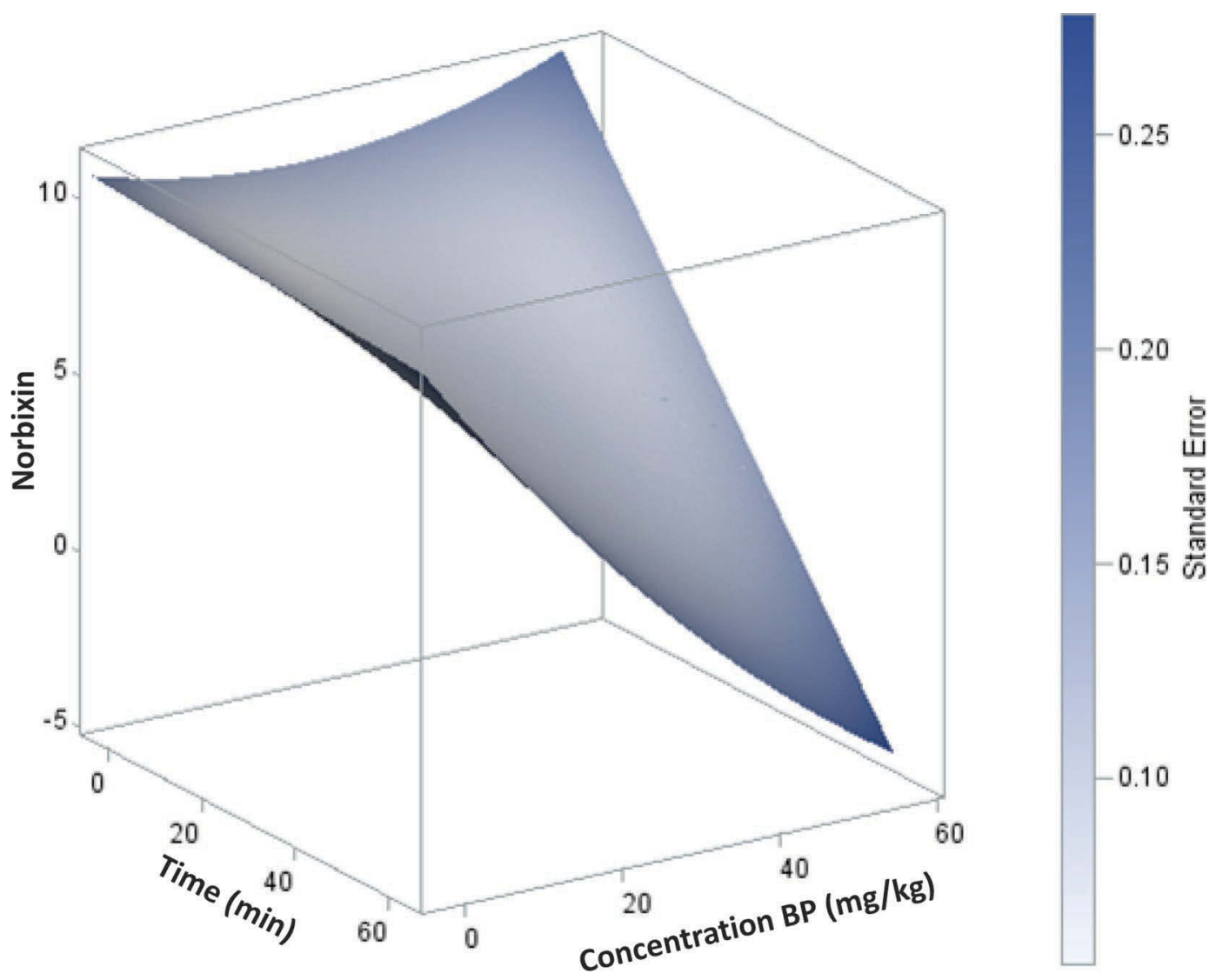

Figure 6. Response surface model of bleaching of fluid whey with soluble benzoyl peroxide (BP) at $50^{\circ} \mathrm{C}$. Prediction equation: percent destruction $=100-\left\{\operatorname{INL}\left[10.23+(\operatorname{conc} \times-0.07)+(\right.\right.$ time $\times-0 .-0.03)+\left(\right.$ conc $\left.^{2} \times 0.001\right)+\left(\right.$ conc $\times$ time $\left.^{\circ} \times-0.003\right)+\left(\right.$ time $\left.\left.e^{2} \times 0.00003\right)\right]+$ $1\} / 161.18$, where INL $=$ inverse $\log$, conc $=$ concentration of $\mathrm{BP}$, time $=$ bleaching time in minutes. Color version available online.

recovery efficiency was much lower in SWP from liquid whey bleached at $14 \%$ solids compared with $6.7 \%$ solids (Jervis et al., 2015). The hypothesis that residual $\mathrm{BP}$ remains in the spray dried powder and continues to cause lipid oxidation is supported by the increased concentration of BA in the dried SWP powder (Jervis et al., 2015). During BP bleaching of liquid whey at higher solids (14\%), more BP breaks down to BA and more protein is available to bind with $\mathrm{BP}$ because of higher solids, whereas less BP breaks down into BA or binds to protein when bleaching occurs at native solids (6.7\%). Residual BP in SWP from liquid whey bleached at native solids $(6.7 \%)$ is free to continue to oxidize lipids in the dried powders. This result also explains the higher concentration of lipid oxidation products in SWP from fluid whey bleached at native solids. Residual BA in the powder is also unable to bind to protein in the dried powder, which would also

Table 1. Mean $(\mathrm{n}=3)$ color $\left(\mathrm{L}^{*}, \mathrm{a}^{*}\right.$, and $\mathrm{b}^{*}$ values $)$ of liquid $(10 \% \mathrm{wt} / \mathrm{vol}$ powders $)$ and spray-dried whey protein concentrate (WPC80) from liquid whey bleached by $5 \mathrm{mg} / \mathrm{kg}$ insoluble (InsolBP) or soluble (SolBP) benzoyl peroxide or unbleached (no bleach) at 4 or $50^{\circ} \mathrm{C}$

\begin{tabular}{|c|c|c|c|c|c|c|}
\hline \multirow[b]{2}{*}{ Item } & \multicolumn{2}{|c|}{ L* (lightness) } & \multicolumn{2}{|c|}{$\mathrm{a}^{*}$ (red-green) } & \multicolumn{2}{|c|}{ b* (yellow-blue) } \\
\hline & Liquid & Powder & Liquid & Powder & Liquid & Powder \\
\hline No bleach & $64.5^{\mathrm{c}}$ & $88.6^{\mathrm{b}}$ & $8.32^{\mathrm{a}}$ & $3.21^{\mathrm{a}}$ & $24.6^{\mathrm{a}}$ & $17.4^{\mathrm{a}}$ \\
\hline InsolBP $4^{\circ} \mathrm{C}$ & $65.4^{\mathrm{c}}$ & $89.5^{\mathrm{b}}$ & $6.05^{\mathrm{b}}$ & $3.35^{\mathrm{a}}$ & $18.8^{\mathrm{b}}$ & $13.7^{\mathrm{b}}$ \\
\hline SolBP $4^{\circ} \mathrm{C}$ & $67.4^{\mathrm{bc}}$ & $89.2^{\mathrm{b}}$ & $5.93^{\mathrm{b}}$ & $3.15^{\mathrm{a}}$ & $14.5^{\mathrm{c}}$ & $12.14^{\mathrm{c}}$ \\
\hline InsolBP $50^{\circ} \mathrm{C}$ & $69.5^{\mathrm{ab}}$ & $93.2^{\mathrm{a}}$ & $2.53^{\mathrm{c}}$ & $1.35^{\mathrm{b}}$ & $13.2^{\mathrm{c}}$ & $9.26^{\mathrm{d}}$ \\
\hline SolBP $50^{\circ} \mathrm{C}$ & $71.4^{\mathrm{a}}$ & $95.2^{\mathrm{a}}$ & $2.13^{\mathrm{c}}$ & $1.05^{\mathrm{b}}$ & $9.5^{\mathrm{c}}$ & $8.31^{\mathrm{e}}$ \\
\hline
\end{tabular}

${ }^{\mathrm{a} e}$ Means in a column not sharing a common superscript are different $(P<0.05)$. 


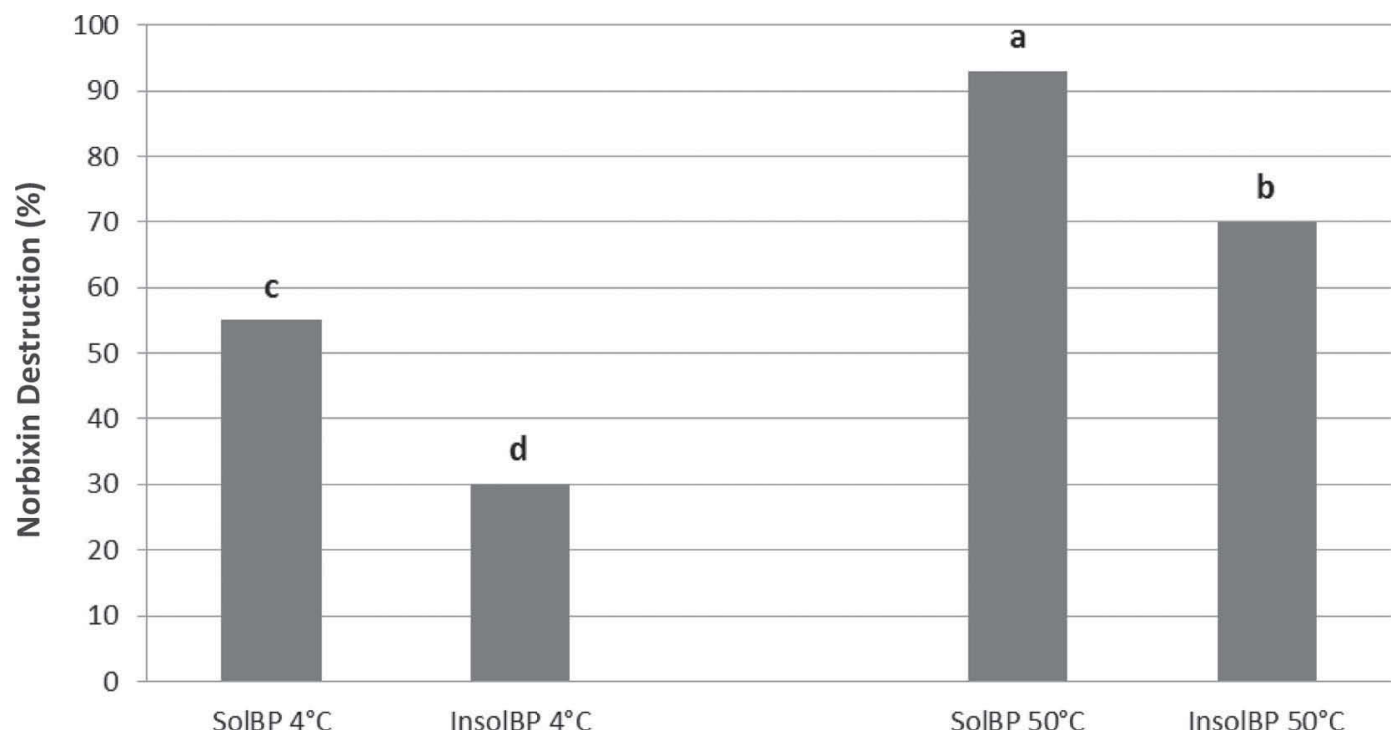

Figure 7. Percent norbixin destruction (actual) in powders of $80 \%$ whey protein concentrate from liquid whey bleached by $5 \mathrm{mg} / \mathrm{kg}$ insoluble (InsolBP) or soluble (SolBP) benzoyl peroxide at 4 or $50^{\circ} \mathrm{C}$ for $1 \mathrm{~h}$. Letters denote statistical differences $(P<0.05)$.

explain the higher extraction efficiency and a higher concentration of residual $\mathrm{BA}$.

In the current study, at $4^{\circ} \mathrm{C}, \mathrm{BP}-$ bleached WPC 80 had higher levels of lipid oxidation than WPC80 bleached by $\mathrm{BP}$ at $50^{\circ} \mathrm{C}$. A lower concentration of $\mathrm{BA}$ in $4^{\circ} \mathrm{C}$-bleached WPC80 UF permeate was present compared with $50^{\circ} \mathrm{C}$-bleached WPC80 UF permeate, which supports the hypothesis that $\mathrm{BP}$ at $4^{\circ} \mathrm{C}$ was not completely decomposed and remained in the UF retentate (Figure 9). Benzoyl peroxide is fat soluble, and if unreacted BP was associated with the fat phase, it would be concentrated during UF processing rather than being expelled into the permeate. It is possible that at lower temperatures, given only $1 \mathrm{~h}$ to bleach, residual insoluble $\mathrm{BP}$ remained in the liquid retentate and subsequent WPC80 powder, whereas at higher

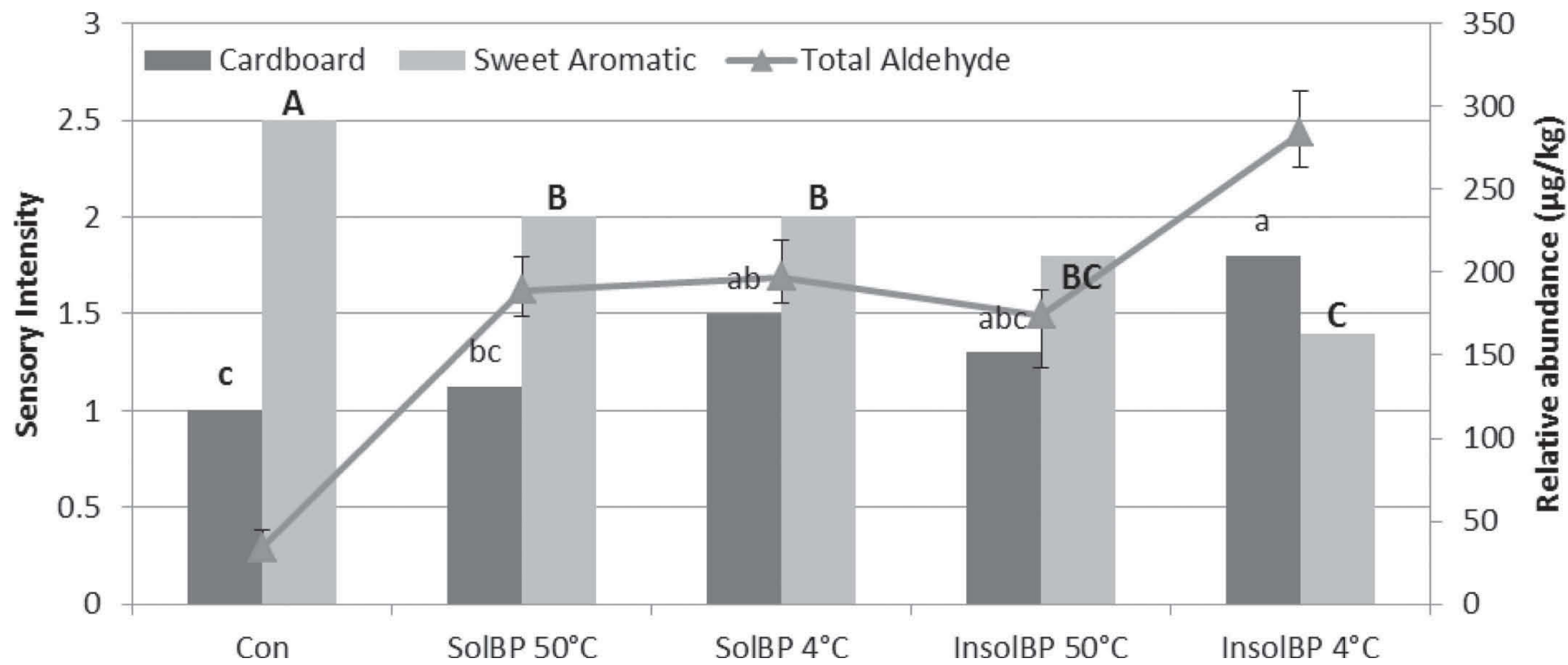

Figure 8. Mean cardboard and sweet aromatic flavor intensities versus total aldehyde relative abundance concentrations ( $\mu \mathrm{g} / \mathrm{kg}$ ) for rehydrated (10\% wt/vol) powders of $80 \%$ whey protein concentrate that were unbleached (Con) or bleached at $5 \mathrm{mg} / \mathrm{kg}$ soluble (SolBP) or insoluble (InsolBP) benzoyl peroxide at 4 or $50^{\circ} \mathrm{C}$. Letters denote statistical differences for each descriptor (cardboard, sweet aromatic; $P<0.05$ ). Note: Uppercase and lowercase letters are used to denote different descriptors. Statistical lettering does not compare across descriptors (cardboard, sweet aromatic). 
temperatures $\left(50^{\circ} \mathrm{C}\right)$, a higher proportion of the $\mathrm{BP}$ was broken down into BA during bleaching. If this was the case, the increased lipid oxidation products associated with the WPC 80 bleached at $4^{\circ} \mathrm{C}$ by insoluble $\mathrm{BP}$ are due to residual $\mathrm{BP}$ continuing to cause lipid oxidation in the dried WPC80 powder. Future studies addressing BA as well as unreacted BP in dried powders would be necessary to confirm this hypothesis.

Sieber et al. (1995) and Qi et al. (2009) reported native BA in dairy products at concentrations as high as $110 \mathrm{mg} / \mathrm{kg}$. A previous study performed by Listiyani et al. (2011) reported WPC34 powders from fluid whey bleached with $50 \mathrm{mg} / \mathrm{kg}$ BP had a BA concentration of $272 \mathrm{mg} / \mathrm{kg}$, and WPC34 powders from fluid whey bleached with $100 \mathrm{mg} / \mathrm{kg}$ BP had a BA concentration of $634 \mathrm{mg} / \mathrm{kg}$, whereas WPC80 from fluid whey bleached with $50 \mathrm{mg} / \mathrm{kg}$ BP had BA concentrations of 30 to $60 \mathrm{mg} / \mathrm{kg}$. Listiyani et al. (2011) demonstrated that BA was removed with UF and DF during WPC production. Water soluble BA was washed out by DF and was detected in the UF permeate. Liquid permeate from the current study also contained BA. Ultrafiltered permeate from liquid whey bleached hot $\left(50^{\circ} \mathrm{C}\right)$ had approximately $6 \times$ higher BA concentration than UF permeate from liquid whey bleached cold $\left(4^{\circ} \mathrm{C}\right)$.

Based on the findings of the current study and Listiyani et al. (2011), it is possible that high protein whey concentrates $(80-89 \%)$ and isolates ( $>90 \%$ protein wt/ wt) could drastically reduce BA by UF and DF. Results from the current study suggest that approximately 5 $\mathrm{mg} / \mathrm{kg}$ soluble BP would provide sufficient norbixin destruction under cold $\left(4^{\circ} \mathrm{C}, 55 \%\right.$ norbixin destruction $)$ or hot bleaching $\left(50^{\circ} \mathrm{C}, 90 \%\right.$ norbixin destruction) conditions within $1 \mathrm{~h}$, and time could be increased to increase bleaching efficacy or BP decomposition. This result suggests possible avenues for reducing BA residues in WPC powders. To decrease BA residues in WPC powders, the lowest possible effective concentration of BP should be used. Diafiltration during processing also decreases BA; however, bleaching temperature and ultimately BP breakdown need to also be accounted for during processing. Listiyani et al. (2012) demonstrated that bleaching before or after fat separation had no effect on volatile compound concentration or norbixin destruction in liquid whey. If $\mathrm{BP}$ is concentrated with the fat phase of the WPC80 retentate during UF, as the

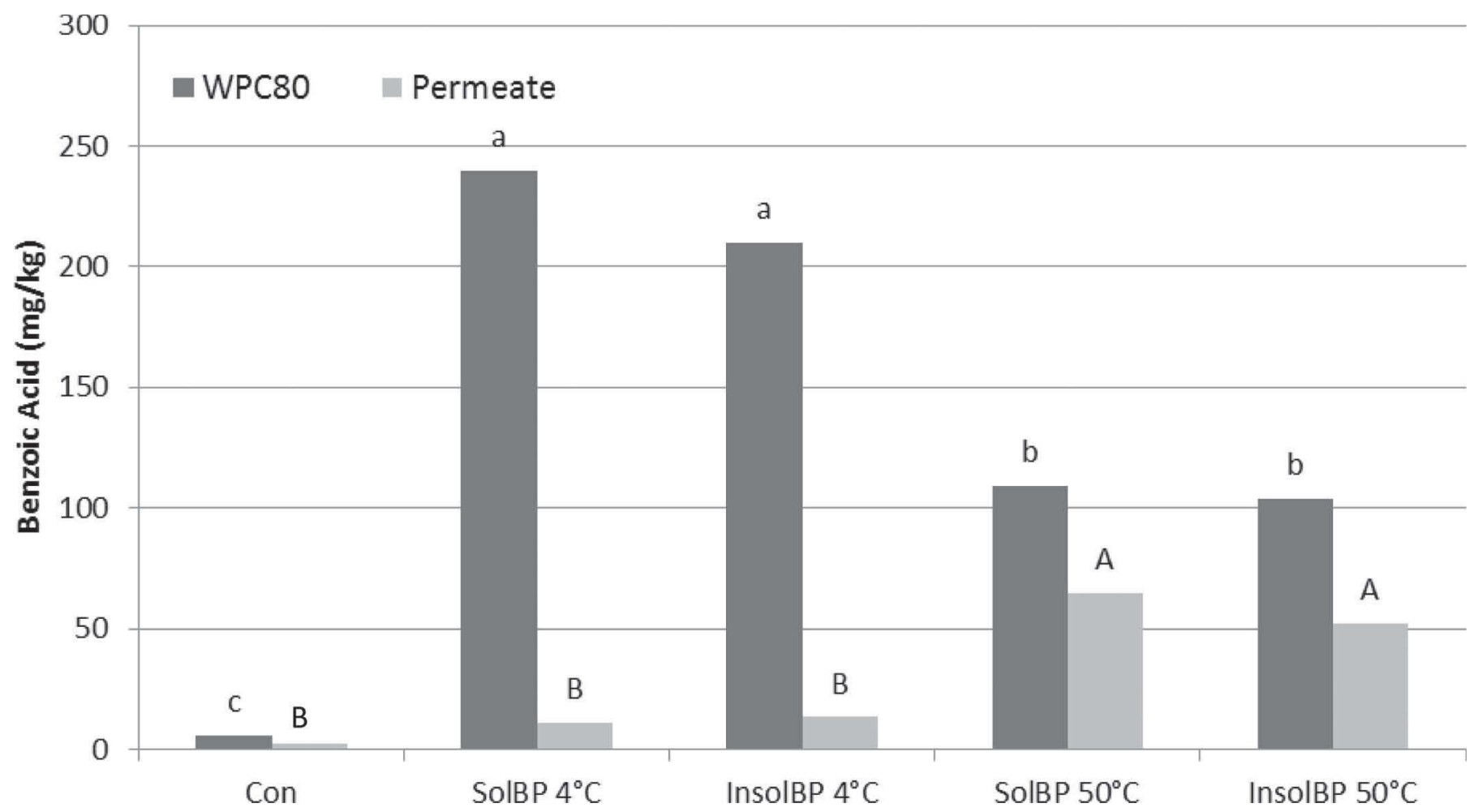

Figure 9. Benzoic acid concentrations $(\mathrm{mg} / \mathrm{kg}$ ) in powder of $80 \%$ whey protein concentrate (WPC80) and UF permeate (solids basis) from liquid whey bleached by $5 \mathrm{mg} / \mathrm{kg}$ insoluble (InsolBP) or soluble (SolBP) benzoyl peroxide at 4 or $50^{\circ} \mathrm{C}$. Letters denote statistical differences within each product (WPC80, permeate; $P<0.05$ ). Note: Uppercase and lowercase letters are used to denote different products. Statistical lettering does not compare across products (WPC80 and permeate). 
current study results suggest, it could be possible to remove remaining BP by bleaching before fat separation, without affecting the volatile composition in the final product. Reducing residual $\mathrm{BP}$ in the fat phase of liquid before UF and DF could further reduce BA residues in the WPC powder. As stated earlier, HP bleaching of fluid whey reduces norbixin concentration by 20 to $44 \%$ at 250 to $500 \mathrm{mg} / \mathrm{kg}$ concentrations at temperatures ranging from 50 to $60^{\circ} \mathrm{C}$ (Jervis et al., 2012; Kang et al., 2012; Fox et al., 2013). The prediction equation from the current study predicts that as little as $0.5 \mathrm{mg} /$ $\mathrm{kg}$ soluble $\mathrm{BP}$ at $50^{\circ} \mathrm{C}$ would be necessary to bleach $40 \%$ of norbixin in liquid whey in $1 \mathrm{~h}$, which would further reduce BA levels in WPC powders compared with bleaching with higher concentrations of BP. The results of experiment 2 suggest that another avenue of $\mathrm{BA}$ residue reduction could be to remove the fat phase of liquid whey after BP bleaching, and subsequently a portion of the remaining $\mathrm{BP}$, when norbixin destruction levels have reached desired levels. In experiment 1,5 $\mathrm{mg} / \mathrm{kg}$ soluble $\mathrm{BP}$ at $50^{\circ} \mathrm{C}$ bleached $40 \%$ of norbixin in liquid whey in $15 \mathrm{~min}$. Removing the fat phase of liquid whey after $15 \mathrm{~min}$ of bleaching could result in lower BA residue in final WPC powder and decrease total processing time. Future work should address residual $\mathrm{BP}$ in WPC80 retentate and the fat phase of liquid whey to confirm this hypothesis.

\section{CONCLUSIONS}

Bleaching of fluid whey is an important processing step in colored liquid whey. Benzoyl peroxide is a more effective and efficient bleaching agent than HP, but residual $\mathrm{BA}$ is a concern, especially in foreign markets. Benzoyl peroxide dispersed in a soluble carrier has been developed for liquid applications but had not been previously directly compared with traditional powdered BP. Soluble BP bleaches liquid whey faster and at lower concentrations. Using soluble BP, less BP is necessary to achieve bleaching equivalent to insoluble $\mathrm{BP}$, resulting in the ability to reduce $\mathrm{BA}$ residues in WPC80 powder. Bleaching liquid whey at a cold temperature $\left(4^{\circ} \mathrm{C}\right)$ resulted in more lipid oxidation, a subsequent increase in cardboard flavor, and more residual $\mathrm{BA}$ in the final powder than bleaching at $50^{\circ} \mathrm{C}$. These results demonstrate that as little as $5 \mathrm{mg} / \mathrm{kg}$ soluble BP can be used to effectively bleach fluid whey with optimum norbixin destruction and minimum $\mathrm{BA}$ residues by bleaching at $50^{\circ} \mathrm{C}$.

\section{ACKNOWLEDGMENTS}

The authors thank Dairy Management Inc. (Rosemont, IL) for funding. Special thanks are extended to
Tom Kozel and Tomas Salvador (King of Prussia, PA) for their time and expertise. The use of trade names does not imply endorsement nor lack of endorsement of those not mentioned.

\section{REFERENCES}

AOAC International. 2000. Official Methods of Analysis. 17th ed. AOAC International, Gaithersburg, MD.

Campbell, R. E., I. A. Boogers, and M. A. Drake. 2014. Short communication: Development of a novel method for the extraction of norbixin from whey and its subsequent quantification via high performance liquid chromatography. J. Dairy Sci. 97:1313-1318.

Campbell, R. E., M. C. Adams, M. A. Drake, and D. M. Barbano. 2013. Effect of bleaching permeate from microfiltered skim milk on $80 \%$ serum protein concentrate. J. Dairy Sci. 96:1387-1400.

Campbell, R. E., and M. A. Drake. 2014. Enzymatic bleaching in commercial colored Cheddar whey retentates. Int. Dairy J. 38:74047413.

Campbell, R. E., R. E. Miracle, and M. A. Drake. 2011. The impact of starter culture and annatto on the flavor and functionality of whey protein concentrate. J. Dairy Sci. 94:1185-1193.

CFIA (Canadian Food Inspection Agency). 2008. Food and Drug Regulations. B.08.049.[S]. Whey. Accessed Apr. 4, 2015. http:// www.inspection.gc.ca/food/labelling/food-labelling-for-industry/ dairy-products/whey-powder/eng/1371835185077/1371835187077.

Chipley, J. R. 1993. Sodium benzoate and benzoic acid. Pages: 11-48 in Antimicrobials in Foods. 2nd ed. P. M. Davidson and A. L. Branen, ed. Marcel Dekker, New York, NY.

Croissant, A. E., E. J. Kang, R. E. Campbell, E. Bastian, and M. A. Drake. 2009. The effect of bleaching agent on the flavor of liquid whey and whey protein concentrate. J. Dairy Sci. 92:5917-5927.

do Nascimento Filho, I., P. Schossler, L. S. Freitas, M. I. S. Melecchi, M. G. R. Vale, and E. B. Caramao. 2004. Selective extraction of benzoic acid from landfill leachate by solid phase extraction and ion-exchange chromatography. J. Chromatogr. A 1027:167-170.

Evans, J. P., J. Zulewska, M. Newbold, M. A. Drake, and D. M. Barbano. 2010. Comparison of composition and sensory properties of $80 \%$ whey protein and milk serum protein concentrates. J. Dairy Sci. 93:1824-1843.

Foegeding, E. A., J. P. Davis, D. Doucet, and M. K. McGuffey. 2002. Advances in modifying and understanding whey protein functionality. Trends Food Sci. Technol. 13:151-159.

Fox, A. J., T. J. Smith, P. D. Gerard, and M. A. Drake. 2013. The influence of bleaching agent and temperature on bleaching efficacy and volatile components of fluid whey and whey retentate. J. Food Sci. 78:C1535-C1542.

JECFA (Joint FAO/WHO Expert Committee on Food Additives). 2004. Evaluation of certain food additives. WHO Technical Report Series, 928. Joint Food and Agriculture Organization/World Health Organization (FAO/WHO) Expert Committee on Food Additives. World Health Org., Geneva, Switzerland.

Jervis, M., T. J. Smith, and M. A. Drake. 2015. Short communication: The influence of solids concentration and bleaching agent on bleaching efficacy and flavor of sweet whey powder. J. Dairy Sci. 98:2294-2302.

Jervis, S., R. E. Campbell, K. L. Wojciechowski, M. A. Drake, and D. M. Barbano. 2012. Impact of bleaching whey on sensory and functional properties of $80 \%$ whey protein concentrate. J. Dairy Sci. 95:2848-2862.

Kang, E. J., T. J. Smith, and M. A. Drake. 2012. Alternative bleaching methods for Cheddar cheese whey. J. Food Sci. 77:C818-C823.

Listiyani, M. A., R. E. Campbell, R. E. Miracle, L. O. Dean, and M. A. Drake. 2011. Influence of bleaching on flavor of $34 \%$ whey protein concentrate and residual benzoic acid concentration in dried whey proteins. J. Dairy Sci. 94:4347-4359.

Listiyani, M. A. D., R. E. Campbell, R. E. Miracle, D. M. Barbano, P. D. Gerard, and M. A. Drake. 2012. Effect of temperature and bleaching agent on bleaching of liquid Cheddar whey. J. Dairy Sci. 95:36-49. 
Meilgaard, M. C., G. V. Civille, and B. T. Carr. 2007. The Spectrum ${ }^{\mathrm{TM}}$ descriptive analysis method. Pages 189-253 in Sensory Evaluation Techniques. CRC Press, Boca Raton, FL.

Miller, G. 2005. Healthy growth ahead for wellness drinks. Food Technol. 59:21-26.

Moriguchi, I., S. Wada, and H. Sano. 1968. Binding of 2-(4'-hydroxyphenylaxo) benzoic acid to bovine serum albumin. Chem. Pharm. Bull. (Tokyo) 16:592-596.

Nair, B. 2001. Final report on the safety assessment of benzyl alcohol, benzoic acid, and sodium benzoate. Int. J. Toxicol. 20:23-50.

National Institute of Standards and Technology. 2005. Wiley Registry. NIST Mass Spectral Library. 8th ed. Wiley, Hoboken, NJ.

O'Connell, J. E., and C. Flynn. 2007. Dairy protein hydrolysates. Pages 537-556 in Handbook of Food Products Manufacturing. Y. H. Hui, ed. John Wiley Sons, Hoboken, NJ.

Park, C. W., E. Bastian, B. Farkas, and M. A. Drake. 2014. The effect of feed solids concentration and inlet temperature on the flavor of spray dried whey protein concentrate. J. Food Sci. 79:C19-C24.

Qi, P., H. Hong, X. Liang, and D. Liu. 2009. Assessment of benzoic acid levels in milk in China. Food Contr. 20:414-418.

Scotter, M. 2009. The chemistry and analysis of annatto food coloring: A review. Food Addit. Contam. 26:1123-1145.

Sharratt, M., A. C. Frazer, and O. C. Forbes. 1964. Study of the biological effects of benzoyl peroxide. Food Cosmet. Toxicol. 2:527538.

Sieber, R., U. Bütikofer, and J. O. Bosset. 1995. Benzoic acid as a natural compound in cultured dairy products and cheese. Int. Dairy J. 5:227-246.

Smith, T. J., X. E. Li, and M. A. Drake. 2014. Short communication: Norbixin and bixin partitioning in Cheddar cheese and whey. J. Dairy Sci. 97:3321-3327.
Smithers, G. W. 2008. Whey and whey proteins-From 'gutter-togold'. Int. Dairy J. 18:695-704.

Tfouni, S. A. V., and M. C. F. Toledo. 2002. Determination of benzoic and sorbic acids in Brazilian food. Food Contr. 13:117-123.

USDA. 2013. GAIN Report: The whey into the South China market. Accessed Apr. 11, 2015. http://gain.fas.usda.gov/ Recent\%20GAIN\%20Publications/The\%20whey\%20into\%20 the\%20South\%20China\%20market_Guangzhou_China\%20-\%20 Peoples\%20Republic\%20of_5-3-2013.pdf.

Wedzicha, B. L., and S. Ahmed. 1993. Distribution of benzoic acid in an emulsion. Food Chem. 50:9-11.

Whitson, M. E., R. E. Miracle, and M. A. Drake. 2010. Sensory characterization of chemical components responsible for cardboard flavor in whey protein. J. Sens. Stud. 25:616-636.

WHO. 1996. Toxicological evaluation of certain food additives. WHP Food Additives Series 37. World Health Org., Geneva, Switzerland.

WHO. 2000. Benzoic acid and sodium benzoate. Concise International Chemical Assessment Document 26. World Health Org., Geneva, Switzerland.

Wright, B. J., S. E. Zevchakn, J. M. Wright, and M. A. Drake. 2009. The impact of agglomeration and storage on flavor and flavor stability of whey protein concentrate 80 and whey protein isolate. J. Food Sci. 74:S17-S29.

Wright, J. M., M. E. Carunchia-Whetstine, R. E. Miracle, and M. A. Drake. 2006. Characterization of a cabbage off-flavor in whey protein isolate. J. Food Sci. 71:C86-C90. 